\title{
WAR AND THE PROBLEM OF PERSONAL RESPONSIBILITY
}

\begin{abstract}
In this article, the author addresses the question whether individual citizens are responsible for the aggressive policy of their national leader by comparing the views of Hannah Arendt, Michael Walzer and Jeff McMahan on the problem of personal responsibility . The author agrees with Arendt and McMahan that responsibility presupposes thinking. Taking into account a number of arguments, the author claims that responsibility should be interpreted as a collective duty. Guilt, however, is found at the individual level. A person may be guilty for his own decisions and be responsible for the decisions of the government, but he could not be condemned for the crimes of the latter. In conclusion, the author claims that this idea applies at the international level as well, because states are collectively responsible for maintaining justice and peace in the world .
\end{abstract}

Keywords: war, responsibility, Walzer, Arendt, McMahan, war crime

1. Introduction. 2. What is Political Responsibility? 3. Responsibility, environment and time.

4. Conclusion.

\section{INTRODUCTION}

The issue of the participation and responsibility of an individual in the life of a state is a moot point in political philosophy. On the one hand, every member of a community is involved in its life. On the other hand, most of us are not usually involved in the political process and do not make political decisions. This puts pressure on the question of personal responsibility. Who is responsible for the decisions made by politicians, and why? This is especially relevant for the decision to start a war. This is a vexed question that scholars, with a few exceptions, tend to avoid. This question becomes even more problematic if we take into account its connection with the question of collective action or inaction. We face this problem, for instance, 
when discussing military and civilian mass crimes committed during the Second World War (not only by Nazi Germany ) or the procrastination of the international community in stopping the Tutsi genocide in 1994.

The question of responsibility in the context of war breaks up into a few components, according to the traditional distinction between jus ad bellum and jus in bello. As a result, responsibility concerns the decision to both start a war and fight in a war. We could probably add a third component stressed by the latest developments in just war theory. This would be jus post bellum, with responsibility involved in this stage of war as well. However, to address the question above we must focus on jus ad bellum, and probably on jus post bellum. The problem of responsibility in the conduct of war, or jus in bello, seems to be hard but it has been examined and discussed to a much greater extent. There are plenty of sources on this matter. Military responsibility has also been discussed at length, and it does not appear to be an issue as complex as the question of the responsibility for the decision to start a war or to end a war and establish peace and order. Moreover, the personal responsibility of politicians and soldiers during a war, and for the crimes of war, has been confirmed by the norms of international law and is universally accepted. But the hard question is - can we assume that every member of a society is responsible for the aggressive policy of their national leader?

This article is an attempt to solve the question of the personal responsibility for the decisions and actions of public officials in the context of war. Our discussion will draw on the ideas of such different thinkers as Michael Walzer, Hannah Arendt, Max Weber and Jeff McMahan.

\section{WHAT IS POLITICAL RESPONSIBILITY?}

In order to answer the question of the extent to which individual people are responsible for the criminal or aggressive policy of their 
state leaders we should define political responsibility first, and describe the social environment that gives significance to the idea of responsibility.

There are different definitions of "responsibility" in ordinary and philosophical language, but we will concentrate on Arendt's definition of this notion. According to Arendt, responsibility is related to judgment. The title of a collection of Arendt's previously unpublished writings is precisely Responsibility and Judgment. ${ }^{1}$ What does "judgment" mean for Arendt? It is not easy to answer this question as Arendt's project to write a book on judgment remains unfinished. Judgment, however, is the key concept in Arendt's Lectures on Kant's political philosophy ${ }^{2}$, which will be the focus of our analysis . The ability to make judgments is described by Arendt as a specific ability to know or to feel the difference between right and wrong, correct and incorrect, permissible and impermissible. Judgment is an ability to work with the particular, while mind can only work with the general. Although our aim here is not to carry out an in-depth analysis of Arendt's interpretation of Kant's Critique of Judgment ${ }^{3}$, it is worth noticing for our purposes that for Arendt the ability to express judgments, as well as to reason, are the crucial and determinative features of a human being. This claim originates in Arendt's analysis of Nazi Germany. She was very impressed by the multiple changes of moral standards within German society: initially, the German people supported Kaiser Wilhelm II, who had started World War I, then they condemned and repudiated him; after supporting the democratic party in the Weimar Republic, the majority of Germans welcomed Hitler, his ideology and aggressive politics and later forgot about him and distanced from his ideas (which they had previously accepted) in a heartbeat. Arendt concluded that the ability to make judgments,

$1 \mathrm{H}$. Arendt, Responsibility and Judgment, New York 2005.

2 H. Arendt, Lectures on Kant's political philosophy, Chicago 1992.

3 I. Kant, Critique of Judgment, trans. by J.H. Bernard, London 1914. 
to distinguish right and wrong, is something deeply rooted in people's minds and it is independent of changing moral standards.

In Arendt's highly original approach, political responsibility is based on the ability to make judgments. In her opinion, however, political responsibility should be understood exclusively as collective responsibility. Arendt separates politics from morality and law. Following Aristotle she treats politics as a common, collective job, whereas morality and law bear relevance at the individual level. Morality and law always concern individuals and their actions; politics concern a whole community.

As she put it: "I would say that two conditions have to be present for collective responsibility: I must be held responsible for something I have not done, and the reason for my responsibility must be my membership in a group (a collective) which no voluntary act of mine can dissolve, that is, a membership which is utterly unlike a business partnership which I can dissolve at will". ${ }^{4}$

Political responsibility is treated by Arendt as a collective affair, a common job. Responsibility is something one could not reject or neglect. One is responsible simply in virtue of being a member of a society. In this sense, we are all responsible for our ancestors and their deeds. In other words, political responsibility for Arendt is a way of political engagement. In addition, what is crucial for her is that collective responsibility does not presuppose collective guilt.

Even if a nation could be responsible for the wrong policy or noble behavior of its political leader, it could not be guilty for his wrong decisions or aggressive politics. Guilt is a concept of law and presupposes individual accountability, whereas responsibility is a political notion and it becomes shared as soon as politics constitutes a public sphere. To repeat, an individual member of a community may be responsible for a wrong action that has been done in the name of the community; in such a case, however, he loses his individual

$4 \mathrm{H}$. Arendt, Responsibility and Judgment, op. cit., 149. 
status. But there is no such thing as collective guilt and collective condemnation.

According to Arendt, it would be proper to assess each person's action individually. That would be as assessment of individual guilt. Collective responsibility belongs to a different level, which closely resembles Michael Walzer's views on soldier equality and personal responsibility. In Just and Unjust Wars, Walzer stated: "Personal choice that the soldier makes on his own and for essentially private reasons (...) effectively disappears as soon as fighting becomes a legal obligation and a patriotic duty (...) For the state decrees that an army of a certain size be raised, and it sets out to find the necessary men, using all the techniques of coercion and persuasion at its disposal". ${ }^{5}$ The idea of responsibility is conjoined here with the idea of necessity. Even if it is not necessary to commit a crime (e.g. to rob a bank) or to watch football this evening, it is sometimes necessary to serve one's country in case of an emergency. The idea of necessity applies to war, and this could morally rehabilitate those who participated in an unjust war. As Walzer argues, guilt for the war they are fighting is not their private guilt; it is the guilt of their political or military leaders.

Arendt reflected on this issue in a similar way: "if the person happens to be involved in a common undertaking as in the case of organized crime, what is to be judged is still this very person, the degree of his participation, his specific role, and so on, and not the group." This may be interpreted as saying that the guilt for war crimes applies to everyone regardless of hierarchy. One cannot simply say that one's role in a crime one is involved in is insignificant.

Arthur Harris (bombing of Dresden), Joachim Peiper (Malmedy massacre), lieutenant Kelly (My Lai), and Russian Colonel Budanov (sentenced for kidnapping and raping a Chechen young girl who he

5 M. Walzer, Just and Unjust Wars, New York 2015, 28.

$6 \mathrm{H}$. Arendt, Responsibility and Judgment, op. cit., 44. 
believed was a terrorist sniper) are responsible for their decisions and actions according to three dimensions, as argued by Walzer: upward to their commanders, downward to their command and outward to those whose lives they affect. ${ }^{7}$ No matter their rank or role, they all bear the burden of the decisions they made. That is the moral and legal aspect of their actions. The passage above suggests that Arendt would certainly agree with this conclusion.

Regardless of how we interpret Arendt's passage, there is another component of this general argument that we must take into account: this is the idea that we should not blame a whole nation for an aggressive war started by its political or military leaders. If there is a wrong decision made by a leader, he should be blamed for it, brought to trial and imprisoned. These measures of punishment, however, should not affect the people, the whole nation.

In other words, political leaders may be accused of violating jus ad bellum; military staff for violating jus in bello. War crimes must be punished - that much is evident and confirmed by International Law, as we said before. An individual decides autonomously whether he should act in an entirely aggressive or absolutely inappropriate way, although it is not always simple and unambiguous to understand what decision is correct or incorrect in a given situation. Many authors argued that there is a moral obligation not to enter an unjust war when its injustice is evident. Francisco de Vitoria urged that it would be better not to join an unjust war "since one may not lawfully kill an innocent man on any authority, and in the case we are speaking of the enemy must be innocent."

This idea finds its supporters in contemporary just war theory. Jeff McMahan does not consider war as having unique and exclusive features (we should note, however, that it is hard to imagine another situation in

7 See: M. Walzer, Two Kinds of Military Responsibility, in: Arguing about War, New Haven 2004, 23-26.

8 F. de Vitoria, On the Law of War, in: Political Writings, Cambridge 2010, 307. 
which a person takes up arms and kills not by his own choice or because of social pressure, but to fulfil his duty to the fatherland and out of loyalty to the ancient tradition and common values of his nation). For McMahan, an unjust war and a criminal act such as a robbery are absolutely the same. He offers a multi-layered argument for this conclusion.

McMahan criticizes St. Augustine, Hobbes, Pufendorf and many other philosophers who claimed that the responsibility for the decision to start a war belongs to a sovereign rather than a soldier. As McMahan notes, this idea was partly due to the authority and power of the sovereign to give orders and demand obedience. In addition, philosophers such as Hobbes claimed that the sovereign is the very source of justice, honesty and law. McMahan breaks with this tradition.

He raises the following question, which also serves to characterize his own position: "why have most people in virtually all countries at all times believed that a person does not act wrongly by fighting in an unjust war, provided that he obeys the principles governing the conduct of war?" From McMahan's point of view, a state could not demand its citizen to act wrongly; if it does, that state is bad and one should resist it. McMahan also argues that taking the state as the responsible party means that soldiers ask forgiveness for their unfair actions without considering that this does not make their actions acceptable and justified. ${ }^{10}$

In other words, McMahan rejects Walzer's idea of the equality of soldiers and argues that people should deliberately refuse to take part in an unjust war, ${ }^{11}$ even if the state is calling them up. If it is not clear whether a war is just or not, it is always better to step aside. The responsibility for using arms in war falls on each individual, who ought to assess the justification for a war and make a decision about his own involvement accordingly.

9 J. McMahan, Killing in War, Oxford 2009, 105.

10 Ibid., 91.

11 Ibid., 95-103. 
It could be noted that Arendt and McMahan are saying almost the same things. We should add, however, that their positions are not entirely identical. Arendt appeals to collective responsibility, whereas McMahan demands individual responsibility. Both presuppose that each person must be responsible, but their emphasis focuses on different aspects. Arendt describes a situation in which each individual is responsible only as a member of a group, a society. Arendt's position presupposes that the responsibility, but not the guilt, for an action falls on the whole society. McMahan's account of responsibility rests on a specific social theory. He describes a society of separate individuals, responsible only for themselves. It is hard to call this a society, given that each person follows only his own aims and decisions. It follows from this view that, if a person is involved in an unjust war he is both responsible and guilty for participating in it, even if his participation is merely passive. Comparing these two approaches, we find McMahan's approach unrealistic and incline to Arendt's understanding of political responsibility.

There is one question related to the problem of personal responsibility. Should we condemn a person who refuses to support his own state fighting a just war? We may recall here Bertrand Russell, who was imprisoned during the First World War for his pacifist activities. That war was just for Britain (let us ignore the question whether it was truly just or not), which made Russell's position unpatriotic and therefore unacceptable. So, Russell was imprisoned for criticizing a war that was commonly understood as just. If a state wages an unjust war and one of its citizens opposes it, he would be a hero, a soldier of justice, and we would evaluate him positively. But what about those who oppose a war that meets all the criteria of jus ad bellum and jus in bello? Should we consider them enemies, criminals or simply madmen? What is their status? Could we demand that a whole nation, or at least the majority of the population, support a just war? Or, rather, if the war is just there is no need to ask citizens, for a decision follows from the charisma 
of the government or political leader? That would be a charismatic decision in Max Weber's sense because we trust the government as if it were gifted with special powers. It has more information and competence than individual citizens, as well a greater experience and more options. It turns out that, when it comes to initiating a just war it does not really matter what the citizens think. People are removed from politics. It is enough for the government to recall its own legitimated authority when making a decision. People's consent is not needed to ensure compliance of governmental actions with jus ad bellum. If a war is unjust, however, questions concerning the responsibility of each individual citizen for the wrong or even criminal decisions of the government are promptly raised. They are meant to urge each individual to think critically, evaluate the actions of the government and, ultimately, take responsibility for the decision to start an unjust war. In this case people return to politics, whereas politicians with their special status and knowledge disappear as such.

\section{RESPONSIBILITY, ENVIRONMENT AND TIME}

We agree with McMahan and Arendt that responsibility presupposes thinking. But thinking is impossible outside the intellectual sphere, without a proper education, training and a habit for critical reasoning. There is no society without this environment. And the dominant system of power is primarily responsible for the lack of thinking.

A political leader who starts a war would probably explain his decision with reference to the norms accepted by the society he represents. Such norms, however, would be interpreted to the best advantage of the ruler. A sovereign uses public morality and adapts it to the form of justice that best serve his purposes. In this sense, we can distinguish between International Law and morality. International Law is a system established by the international community, and it is not subject to rapid changes. National morality or ideology, on the other hand, can be affected by politicians or military leaders. There 
are many examples of dramatic conversions of the collective conscious in the $20^{\text {th }}$ century. Russia and Germany are two notable cases, but they are not the only examples of how people who devotedly support one ideology with a specific moral code rapidly shifted to a different one several times in the span of one generation. Such examples show that sometimes a different interpretation of morality could be used deliberately to justify an unjust war. Although we are unable to consider thoroughly this problem here, it is worth mentioning Brian Orend's theory of "minimally just" political community in this context. As Orend states, a political community is "minimally just" when: 1) it is generally recognized by its own people and the international community, 2) it avoids violating the rights of other countries, and 3) it makes every reasonable effort to satisfy the human rights of its own citizens. ${ }^{12}$ Any state or political group could be a "minimally just" community, regardless of the political parties currently in office. The only requirement is that a government act in accordance with the criteria listed above. Orend assumes that only minimally just communities are able to wage just wars and fulfill the criteria of just ad bellum, in bello and post bellum. If a state is not minimally just, it will always resort to armed force unjustly. This theoretical scheme, projected into a broader political landscape, could serve to identify, in some cases at least, nations acting wrongly from a moral point of view, even if they use all political, social and media resources to justify their actions.

There is one more problematic aspect of politics relating to the question of responsibility - i.e., the problem of time. We may say our that own responsibility derives from the fact that we voted for the politicians currently in office. It was our own choice to elect them and, therefore, to have responsibility for them. Hence, if our leader decides to unleash a war we should agree with this decision given that we have supported him during the elections. We should also

12 B. Orend, The Morality of War, Peterborough, Ontario 2006, 35-36. 
note, however, that the people in power can change their principles and positions, and that sometimes such changes can be dramatically substantial. Hitler and Stalin are radical examples of this idea - both were legitimated leaders of their states (setting aside the question whether they gained power legally or not) who committed political crimes. When should we decline to fulfill the illegal decisions of our leaders? This is a very complicated issue as political decisions can be taken rapidly, and people may be e unable to react to them with equal speed. Society is a very inert system that is not ready to respond to fast changes in government rhetoric. This, in turn, makes social control very diverse in its deployment. Society and individuals are not always ready for deep political thinking. If we accept collegial responsibility and guilt for the crimes of political leaders, then people who tried to stay out of politics would be punished as well. Moreover, failure to comply with government directives may have different consequences in different countries. In free countries, it may take the form of simple disobedience or protest; in more closed societies, insubordination and opposition would meet with a lack of understanding from the authorities and society at large, as well as face ostracism or even persecution and imprisonment

\section{CONCLUSION}

To sum up, a state leader represents the will of the people and that is why he is responsible for its improper usage. An individual cannot be condemned for an unfair decision of the sovereign, because his influence on politicians is hesitant . This is due to a fear common to people. Fear for their life makes people obedient as they realize they are powerless against the political leader or the political community. That means a person could be condemned for his own crimes and wrong decisions, and that there is no such thing as collective guilt. On the other hand, it is the whole society that bears responsibility for the politics of their state. 
This reasoning holds only during the decision making process, when jus ad bellum or jus post bellum principles could be violated. Once a conflict develops, jus in bello principles as well as personal involvement and responsibility for possible injustice come into play. Developing a multilateral approach, we add that Arendt's arguments show their validity at both the international and intranational levels. If a state decides to start a war, or makes any other decision in foreign policy, responsibility for this decision falls partly on the international community, for international opposition to wrong intentions could sometimes prevent serious troubles or even catastrophes. In other words, the states are collectively responsible for maintaining justice and peace in the world .

\section{BIBLIOGRAPHY}

Arendt H, Lectures on Kant's political philosophy, The University of Chicago Press, Chicago 1992.

Arendt H, Responsibility and Judgment, Schocken Books, New York 2005.

Kant I, Critique of Judgment, trans. by J.H. Bernard, MacMillan and Co., London 1914.

McMahan J, Killing in War, Oxford University Press, Oxford 2009.

Orend B, The Morality of War, Broadview Press, Peterborough, Ontario 2006.

Vitoria F de, On the Law of War, in: Political Writings, Cambridge University Press, Cambridge 2010.

Walzer M, Just and Unjust Wars, Basic Books, New York 2015.

Walzer M, Two Kinds of Military Responsibility, in: Arguing about War, Yale University Press, New Haven 2004, 23-32.

This article was written within the framework of the Academic Fund Program at the National Research University Higher School of Economics (HSE) in 2015- 2016 (grant №15-01-0141), thanks to the financial support of a subsidy granted to the HSE by the Government of the Russian Federation for the implementation of the Global Competitiveness Program.

Arseniy Kumankov

akumankov@hse.ru

National Research University Higher School of Economics

21/4 Staraya Basmannaya, 105066 Moscow, Russia

DOI: 10.21697/spch.2017.53.3.06 